\title{
Vascular Dysfunction Induced by Mercury Exposure
}

\author{
Tetsuya Takahashi ${ }^{1, *}$ and Takayoshi Shimohata ${ }^{2, *}$ \\ 1 Department of Neurology, National Hospital Organization Nishiniigata Chuo Hospital, \\ Niigata 950-2085, Japan \\ 2 Department of Neurology, Gifu University Graduate School of Medicine, Gifu 501-1194, Japan \\ * Correspondence: takahasi@bri.niigata-u.ac.jp (T.T.); shimo@gifu-u.ac.jp (T.S.)
}

Received: 22 February 2019; Accepted: 16 May 2019; Published: 16 May 2019

\begin{abstract}
Methylmercury ( $\mathrm{MeHg}$ ) causes severe damage to the central nervous system, and there is increasing evidence of the association between $\mathrm{MeHg}$ exposure and vascular dysfunction, hemorrhage, and edema in the brain, but not in other organs of patients with acute $\mathrm{MeHg}$ intoxication. These observations suggest that $\mathrm{MeHg}$ possibly causes blood-brain barrier (BBB) damage. $\mathrm{MeHg}$ penetrates the BBB into the brain parenchyma via active transport systems, mainly the L-type amino acid transporter 1, on endothelial cell membranes. Recently, exposure to mercury has significantly increased. Numerous reports suggest that long-term low-level MeHg exposure can impair endothelial function and increase the risks of cardiovascular disease. The most widely reported mechanism of $\mathrm{MeHg}$ toxicity is oxidative stress and related pathways, such as neuroinflammation. $\mathrm{BBB}$ dysfunction has been suggested by both in vitro and in vivo models of $\mathrm{MeHg}$ intoxication. Therapy targeted at both maintaining the BBB and suppressing oxidative stress may represent a promising therapeutic strategy for $\mathrm{MeHg}$ intoxication. This paper reviews studies on the relationship between $\mathrm{MeHg}$ exposure and vascular dysfunction, with a special emphasis on the BBB.
\end{abstract}

Keywords: blood-brain barrier; methylmercury; vascular endothelial growth factor; L-type amino acid transporter 1

\section{Introduction}

Mercury is one of the most toxic heavy metals. Mercury exists in the environment in three forms: elemental, inorganic, and organic. Although elemental and inorganic mercury can cause human health problems, exposure to these forms is generally limited to certain subpopulations, e.g., people working in the manufacturing of mercury-containing drugs or dentists using dental amalgam. Methylmercury $(\mathrm{MeHg})$ is the most common and toxic form of organic mercury. In humans, mercury is readily absorbed into the body, which has no active excretion system for this element [1]. MeHg severely damages the central nervous system (CNS), and increasing evidence shows an association between $\mathrm{MeHg}$ exposure and vascular dysfunction.

In the 1950s, industrial waste containing MeHg caused severe poisoning, the so-called "Minamata disease" and "Niigata Minamata disease", in Japan [2-6]. MeHg bioaccumulates through the food chain; thus, people who ingested highly contaminated fish and shellfish were affected. Clinical manifestations of these diseases include cerebellar ataxia, concentric constriction of the visual field, and sensory and auditory disturbances. The specific symptoms depend on the lesions induced by $\mathrm{MeHg}$, which includes damage to the cerebellum and occipital lobes. However, the underlying mechanism of $\mathrm{MeHg}$-induced selective tissue vulnerability remains to be elucidated. Post-mortem pathological studies of the abovementioned diseases showed petechial hemorrhage and edema in the brains of patients with severe disability [7]. This suggests that MeHg possibly causes blood-brain barrier (BBB) damage. Numerous studies have shown that long-term exposure to small amounts of mercury affects 
endothelial cells and may be associated with an increased risk of cardiovascular diseases [8,9]. MeHg is found not only in industrial waste, but also occurs in nature, where it is formed through microbial methylation of mercury. Although extensive artificial $\mathrm{MeHg}$ pollution has not occurred recently, emissions of mercury into the atmosphere from human activities such as gold mining or fossil fuel burning are increasing and are regarded as a public health concern $[8,10]$. Mercury may also have adverse effects on child development and is considered one of the top 10 chemicals of major public health concern by the World Health Organization [11].

This paper reviews studies on the relationship between $\mathrm{MeHg}$ exposure and vascular dysfunction, with a special emphasis on the BBB to raise awareness of the importance of BBB dysfunction in MeHg-induced toxicity.

\section{Systemic Vascular Effects of MeHg Intoxication}

In contrast to the abovementioned $\mathrm{MeHg}$ intoxication due to exposure to relatively high amounts, most studies have investigated cardiovascular effects caused by long-term low-dose MeHg exposure. One major source of continuous $\mathrm{MeHg}$ exposure is fish, especially large carnivorous fish such as tuna, which bioaccumulate $\mathrm{MeHg}$ at high concentrations [12]. Another source is grain crops grown on contaminated soil near gold mines [13] or coal-fired power plants [14] in developing countries. Since the 1990s, numerous reports have suggested that long-term consumption of these contaminated foods may cause hypertension or be associated with an increased risk of ischemic heart disease [8]. In the area around Minamata bay, where the Minamata disease outbreak occurred, the incidence of hypertension increased during the period of $\mathrm{MeHg}$ exposure and subsequently decreased [15]. Numerous studies have shown a positive correlation between mercury exposure and hypertension or cardiovascular events [16-19].

Diverse molecular mechanisms underlie these cardiovascular risks, and the most widely reported is damage to vascular endothelial cells induced by oxidative stress produced in response to $\mathrm{MeHg}$. It is not clear how MeHg raises the production of oxidative agents, but several studies have shown that $\mathrm{MeHg}$ induces both a decrease in antioxidant activity and an increase in oxidative stress. Oxidative stress via various pathways induces endothelial inflammation, resulting in endothelial dysfunction [20,21]. MeHg has a high affinity for sulfhydryl groups, including glutathione, and thus can bind and inhibit several antioxidants in the blood [22-24]. Decreases in glutathione levels and glutathione-related enzymes have been observed in animal [25,26] and human [27-29] studies. MeHg also has a high affinity for selenium compounds, and this leads to decreased antioxidant activity of selenium-containing enzymes, such as glutathione peroxidase [30,31]. Polymorphisms in antioxidant genes, such as glutathione-related genes, in mercury-exposed regions have been associated with methylmercury retention and risk of myocardial infarction [32-34]. In addition, $\mathrm{MeHg}$ is thought to induce oxidative agents independently of its effects on antioxidants [35,36]. Increased oxidative agents induce mitochondrial dysfunction through mitochondrial DNA damage and respiratory changes and activate a positive feedback loop, resulting in the generation of more oxidants.

Endothelial cells are vulnerable to oxidative stress, which when increased by $\mathrm{MeHg}$ causes endothelial dysfunction, leading to the development of atherosclerosis, thrombosis, vasospasm, and inflammation $[37,38]$. Consequently, it is associated with risk of atherothrombotic diseases, such as hypertension, cerebrovascular diseases, renal dysfunction, and acute myocardial infarction [39-43]. In addition, $\mathrm{MeHg}$ reduces endothelial cell formation and migration [44,45], stimulates vascular smooth muscle cell proliferation [46], and causes platelet activation $[47,48]$ or increases the activity of several coagulation factors, such as factor XIII [49], resulting in a tendency toward hypercoagulation. These effects concomitantly increase the risk of atherosclerotic vascular disease.

\section{CNS Effects of MeHg Intoxication}

The CNS is the organ system most susceptible to MeHg toxicity, and CNS selectivity is mediated by the efficient transport of $\mathrm{MeHg}$ into the brain. MeHg interacts with and binds to sulfhydryl group 
molecules, such as L-cysteine. The MeHg-L-cysteine complex is a substrate for the L-type amino acid transporter 1 (LAT1), which actively transports MeHg across membranes [50]. LAT1 is expressed in various types of brain cells, including neurons, and tissue distribution studies have shown that LAT1 is expressed at higher levels in brain tissue than in other organs [51]. In vitro studies have shown increased MeHg uptake in cells overexpressing LAT1, whereas the uptake of MeHg-L-cysteine and $\mathrm{MeHg}$ cytotoxicity were attenuated after LAT1 knockdown [52].

Several mechanisms underlie the toxicity of $\mathrm{MeHg}$ towards neuronal cells, including its affinity for sulfhydryl groups. MeHg interacts with sulfhydryl groups of tubulin in microtubules [53,54], which are important in CNS development, and thus inhibits their organization. MeHg also affects gamma-aminobutyric acid receptors by its action on sulfhydryl groups [55] and modifies the $\mathrm{N}$-methyl-D-aspartate receptor system [56,57]. However, the most extensively studied and confirmed mechanism is related to the oxidative stress induced by $\mathrm{MeHg}$ [58-60], which is one of the reasons why MeHg primarily affects the brain. The brain consumes oxygen at a high rate and is a rich source of fatty acids and metals, and therefore is more prone to oxidative stress. MeHg decreases cellular antioxidant activity by directly interacting with antioxidants or selenium. Neurons have more limited defense functions against oxidative stress than other brain cells, such as astrocytes. Therefore, neurons are vulnerable to oxidative stress and are considered to be impaired by oxidative stress in various diseases, including cerebrovascular disease [61,62], Parkinson's disease [63-65], Alzheimer's disease [66-68], amyotrophic lateral sclerosis [69-71], and other neurodegenerative diseases. Numerous studies have shown that the presence of antioxidant or selenium reduces $\mathrm{MeHg}$ toxicity both in vivo and in vitro [72-75].

There have been several reports on the relationship between $\mathrm{MeHg}$ and immunoreactions. Proinflammatory cytokines, such as interleukin-6 and tumor necrosis factor-alpha, are highly expressed in $\mathrm{MeHg}$ intoxication models [76-78]. However, these reactions are commonly seen in tissues exposed to oxidative stress; therefore, it is possible that these immune responses are responses to oxidative stress. These cytokines stimulate microglia, leading to changes in microglial polarization and subsequent induction of cellular damage [79].

\section{MeHg Causes BBB Dysfunction In Vitro}

Endothelial cells are also damaged by oxidative stress. Hemorrhage and edema are seen in the brains but not in the systemic vessels of patients with $\mathrm{MeHg}$ intoxication. $\mathrm{MeHg}$ causes dysfunction of systemic vessels and increased risk of ischemic heart disease or hypertension, but there are only a few reports on associations between $\mathrm{MeHg}$ exposure and increased risk of cerebrovascular diseases. These phenotypic differences in vascular dysfunction between the brain and systemic vessels may be caused by structural differences, e.g., vessels with or without BBB. The BBB is composed of brain microvascular endothelial cells, pericytes, astrocytes, and a noncellular component, the basement membrane. The differential vascular reactivity may be due to differences in the reactivity of cells that constitute the BBB other than endothelial cells, namely pericytes and astrocytes. Pericytes surround the endothelial cells and their contraction and relaxation regulate microcirculation [80]. Pericytes also play an important role in vascular remodeling; for example, they secrete extracellular matrix proteins to support vascular integrity [81-83]. Astrocytes are attached to the basement membrane of vessels and neurons by end feet processes that extend from the cell body. Astrocytes are thought to maintain cellular homeostasis by regulating water, ion, and amino acid balances through interaction with neurons and endothelial cells [84-86]. Astrocytes have high levels of antioxidants, including glutathione-related enzymes, which may be suppressed by $\mathrm{MeHg}$ intoxication $[87,88]$.

The BBB controls the selective delivery of molecules from the blood to the brain parenchyma. Disruption of the BBB allows inappropriate molecules or cells to penetrate the brain, causing serious damage. It has been hypothesized that when inflammatory cells and cytokines infiltrate the brain parenchyma, uncontrolled inflammatory responses might occur and injure the brain tissue around the vessels. This has been considered a potential pathological mechanism in several diseases, such 
as cerebral ischemia, viral encephalitis, and traumatic brain injury [89-91]. Dysfunction of any of the three cell types of the BBB, which play different critical roles in maintaining vascular integrity, can impair the barrier function. MeHg passes the BBB mainly via LAT1 on endothelial cells [1]. Similar to all other endothelial cells in the body, brain endothelial cells are impaired by MeHg-induced oxidative stress. MeHg inhibits the proliferation of endothelial cells $[44,92]$ by reducing the expression of fibroblast growth factor-2 [93]. The expression of vascular endothelial growth factor (VEGF) and VEGF receptor-1/-2 in endothelial cells is upregulated after MeHg exposure [94]. VEGF, which is important for endothelial cell migration, proliferation, and maturation, induces hyperpermeability of vessels, resulting in vascular leakage and edema [95].

Pericytes also express LAT1, and they are relatively more vulnerable to $\mathrm{MeHg}$ than endothelial cells because they express lower amounts of protective sulfhydryl-containing molecules [96]. Pericyte contraction is induced by oxidative stress, leading to BBB breakdown and blockage of the microvascular blood flow [97]. Pericytes secrete hyaluronan, one of the extracellular matrix components. Hyaluronan has strong water retention ability and regulates the water content of the extracellular fluid. After MeHg exposure, hyaluronan secretion from pericytes is increased [98], which might be one of the causes of brain edema seen in the brains of patients with $\mathrm{MeHg}$ intoxication.

Astrocytes have high antioxidant capacity and protect neurons from oxidative stress. However, astrocytes are also subject to oxidative stress as they are vulnerable to oxidative stress when cultured with neurons. Astrocytes show higher uptake of $\mathrm{MeHg}$ and glutamate in coculture with neurons than in monoculture, indicating that they protect neurons from toxicity [99]. In addition, aquaporin-4 (AQP4) inhibition by $\mathrm{MeHg}$ may contribute to dysfunction of astrocytes. AQP4 is a member of the aquaporin family of water channel proteins. It is distributed predominantly in the mammalian brain and is specifically expressed in the end feet of astrocytes [100]. Mercury is a strong inhibitor of AQP4 [101]. AQP4 regulates the cerebral water balance and is involved in edema development induced by several neurological diseases, such as cerebral ischemia, subarachnoid hemorrhage [102,103], acute water intoxication [104], and traumatic brain injury $[105,106]$. Although the exact mechanism underlying edema formation associated with AQP4 is unclear, $\mathrm{MeHg}$ possibly affects the water-regulating function of astrocytes.

A study in an in vitro BBB model using primary porcine brain capillary endothelial cells revealed that both organic and inorganic mercury induced hyperpermeability of the BBB [107]. While in vitro experiments suggest that BBB disruption occurs if one of the three types of cells of the BBB is impaired, there are no reports that directly show that the dysfunction of astrocytes or pericytes induces BBB disruption.

\section{MeHg Causes BBB Dysfunction In Vivo}

It remains to be confirmed whether $\mathrm{MeHg}$ induces BBB disruption and worsens tissue damage in vivo. A recent study demonstrated that $\mathrm{MeHg}$ induces VEGF expression in cultured endothelial cells. Increased VEGF expression results in hyperpermeability not only of systemic vessels, but also of the BBB. BBB leakage leads to hemorrhage, edema, and microcirculation failure in a number of diseases [95]. Therefore, we investigated whether MeHg causes BBB damage by inducing VEGF expression in vivo using a rat model of subacute $\mathrm{MeHg}$ intoxication [108]. The model was established by exposing the rats to 20-ppm MeHg for up to four weeks, which caused severe pathological changes in the cerebellum, although there were no significant differences in mercury content among the different brain regions. BBB damage in the cerebellum after MeHg exposure was examined based on extravasation of endogenous immunoglobulin $\mathrm{G}$ (IgG). The passage of IgG into the brain is usually very limited, and immunohistochemical staining revealed that $\operatorname{Ig} G$ was detected in the brain parenchyma only in the $\mathrm{MeHg}$ exposure group (Figure 1a). In addition, the expression of rat endothelial cell antigen-1 (RECA-1), an endothelial cell marker, was reduced in the MeHg exposure group. Next, we examined the effect of MeHg exposure on VEGF expression. VEGF expression was markedly increased in the cerebellum and mildly in the occipital lobe following MeHg exposure (Figure 1b). We also investigated 
the cellular localization of VEGF using antibodies against the astrocyte marker glial fibrillary acidic protein (GFAP) and RECA-1. VEGF was expressed on the outer side of RECA-1-positive endothelial cells, and most of the VEGF-expressing cells were GFAP-positive astrocytes. In MeHg-exposed rats, intravenous administration of anti-VEGF neutralizing antibody mildly reduced the rate of observed hind-limb crossing signs, a standard motor functional sign considered an expression of limb ataxia in animal models of $\mathrm{MeHg}$ intoxication. Thus, we demonstrated that $\mathrm{MeHg}$ induces BBB damage by upregulating VEGF expression in the BBB in vivo. In our study, upregulation of VEGF was detected only in the cerebellum. The BBB of the cerebellum is thought to be more vulnerable than that of the cerebrum because the expression levels of tight junction proteins and $P$-glycoprotein, one of the barrier proteins, are lower in the cerebellum than in the cerebrum $[109,110]$. Moreover, vascular permeability reportedly is increased more strongly in the cerebellum than in the cerebrum in nonphysiological conditions, such as inflammation [109-112]. The selective damage, hemorrhage, and edema in the cerebellum as seen in the brains of patients may be explained in part by the specificity of VEGF expression in the cerebellum. Increased VEGF expression causes vascular hyperpermeability, which exacerbates several disease conditions [113-115]. Administration of anti-VEGF neutralizing antibody suppressed the deteriorative effect in our experiment [108] as well as in these conditions [113,114].



(a)

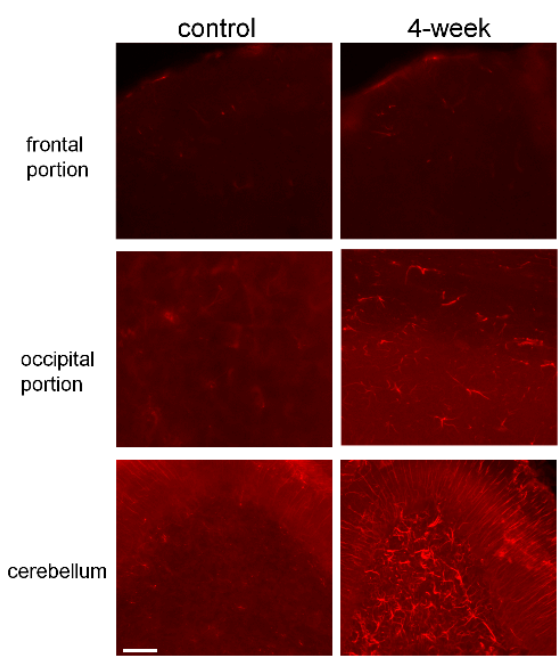

(b)

Figure 1. (a) Immunoglobulin $\mathrm{G}$ (IgG) extravasation in rat cerebellum exposed to methylmercury $(\mathrm{MeHg})$. Rat cerebellum sections from control and 4-week exposure groups (upper and lower panels, respectively) were stained with antibody against rat IgG. Vascular hyperpermeability was evaluated by immunostaining intrinsic IgG outside vessels in control and 4-week exposure groups. Arrows indicate IgG extravasation in the 4-week MeHg exposure group. No IgG staining was detected outside vessels in the control group. Scale bar: $25 \mu \mathrm{m}$. (b) Vascular endothelial growth factor (VEGF) expression associated with $\mathrm{MeHg}$ exposure. Immunohistochemical staining was performed using rabbit anti-VEGF antibody to detect VEGF expression in the frontal and occipital regions and cerebellum of rats in control and 4-week MeHg exposure groups (left and right panels, respectively). Scale bar: $50 \mu \mathrm{m}$.

To date, there are no established therapies to treat mercury poisoning. Chelating therapy, which accelerates the excretion of mercury $[116,117]$, is recommended, particularly in the early phase of mercury exposure. However, evidence for the beneficial effect of chelation therapy is limited, and chelating therapy occasionally induces adverse effects, including sudden cardiac death, because chelators also increase the excretion of essential metals. In addition, in the USA, inappropriate use of chelating agents promoted by alternative medicine societies without essential clinical examination for mercury exposure has raised concern. Although there might be beneficial effects in some cases, chelating agents should be used with caution. While chelating therapy alone is not sufficient to improve 
symptoms, it is possible that combinations with other therapeutic approaches, such as antioxidant or anti-VEGF neutralizing therapy, can reduce the toxicity of mercury. Combination therapy aimed at maintaining the BBB, suppressing oxidative stress, and chelation may have a synergic and thus better effect.

\section{Summary}

- $\mathrm{MeHg}$ causes severe damage to the CNS. MeHg penetrates the BBB into the brain parenchyma via active transport systems, mainly LAT1, on membranes of endothelial cells.

- Growing evidence suggests that even low-level MeHg exposure can induce endothelial dysfunction and increase the risk of cardiovascular disease.

- The most widely reported mechanism of MeHg toxicity is oxidative stress and its consequences, such as neuroinflammation.

- VEGF upregulation is observed after MeHg exposure in vitro and in vivo. The selective damage in the cerebellum after MeHg exposure may be explained in part by the specificity of VEGF expression in the cerebellum.

- BBB dysfunction has been suggested by studies on in vitro and in vivo models of MeHg intoxication, and therefore, maintaining the BBB may represent a promising therapeutic strategy for the treatment of $\mathrm{MeHg}$ intoxication.

Author Contributions: T.T. conceived and designed the review; T.S. revised the draft; T.T. wrote the paper.

Funding: This work was supported by JSPS KAKENHI via grant number 24659426 (to T.S.). This work was also supported by the Niigata Prefecture Grant-in-Aid for Minamata Disease research via grant number J15J0031 (to M.N.). The funders had no role in the study design, data collection and analysis, decision to publish, or preparation of the manuscript.

Conflicts of Interest: Takayoshi Shimohata is an academic adviser of the ShimoJani LLC biotech company. The other authors declare no conflict of interest. The founding sponsors had no role in the design of the study; in the collection, analyses, or interpretation of data; in the writing of the manuscript; or in the decision to publish the results.

$\begin{array}{ll}\text { Abbreviations } \\ \text { MeHg } & \text { Methylmercury } \\ \text { BBB } & \text { Blood-brain barrier } \\ \text { CNS } & \text { Central nervous system } \\ \text { LAT1 } & \text { L-type amino acid transporter 1 } \\ \text { VEGF } & \text { Vascular endothelial growth factor } \\ \text { AQP4 } & \text { Aquaporin-4 } \\ \text { RECA-1 } & \text { Rat endothelial cell antigen-1 } \\ \text { IgG } & \text { Immunoglobulin G }\end{array}$

\section{References}

1. Bridges, C.C.; Zalups, R.K. Mechanisms involved in the transport of mercuric ions in target tissues. Arch. Toxicol. 2017, 91, 63-81. [CrossRef]

2. Eto, K. Pathology of Minamata disease. Toxicol. Pathol. 1997, 25, 614-623. [CrossRef] [PubMed]

3. Igata, A. Epidemiological and clinical features of Minamata disease. Environ. Res. 1993, 63, 157-169. [CrossRef]

4. Yorifuji, T.; Tsuda, T. Epidemiological studies of neurological signs and symptoms and blood pressure in populations near the industrial methylmercury contamination at Minamata, Japan. Arch. Environ. Occup. Health 2016, 71, 231-236. [CrossRef] [PubMed]

5. Yorifuji, T.; Kashima, S.; Suryadhi, M.A.H.; Abudureyimu, K. Temporal trends of infant and birth outcomes in Minamata after severe methylmercury exposure. Environ. Pollut. Barking Essex 1987 2017, 231, 1586-1592. [CrossRef] [PubMed] 
6. Shimohata, T.; Hirota, K.; Takahashi, H.; Nishizawa, M. [Clinical aspects of the Niigata Minamata disease]. Brain Nerve Shinkei Kenkyu No Shinpo 2015, 67, 31-38. [PubMed]

7. Eto, K.; Takizawa, Y.; Akagi, H.; Haraguchi, K.; Asano, S.; Takahata, N.; Tokunaga, H. Differential diagnosis between organic and inorganic mercury poisoning in human cases-the pathologic point of view. Toxicol. Pathol. 1999, 27, 664-671. [CrossRef]

8. Genchi, G.; Sinicropi, M.S.; Carocci, A.; Lauria, G.; Catalano, A. Mercury Exposure and Heart Diseases. Int. J. Environ. Res. Public. Health 2017, 14, 74. [CrossRef] [PubMed]

9. Solenkova, N.V.; Newman, J.D.; Berger, J.S.; Thurston, G.; Hochman, J.S.; Lamas, G.A. Metal pollutants and cardiovascular disease: mechanisms and consequences of exposure. Am. Heart J. 2014, 168, 812-822. [CrossRef]

10. Sherman, L.S.; Blum, J.D.; Basu, N.; Rajaee, M.; Evers, D.C.; Buck, D.G.; Petrlik, J.; DiGangi, J. Assessment of mercury exposure among small-scale gold miners using mercury stable isotopes. Environ. Res. 2015, 137, 226-234. [CrossRef] [PubMed]

11. WHO. Ten Chemicals of Major Public Health Concern. Available online: https://www.who.int/ipcs/ assessment/public_health/chemicals_phc/en/ (accessed on 22 February 2019).

12. Hsu-Kim, H.; Kucharzyk, K.H.; Zhang, T.; Deshusses, M.A. Mechanisms regulating mercury bioavailability for methylating microorganisms in the aquatic environment: a critical review. Environ. Sci. Technol. 2013, 47, 2441-2456. [CrossRef]

13. Esdaile, L.J.; Chalker, J.M. The Mercury Problem in Artisanal and Small-Scale Gold Mining. Chem. Eur. J. 2018, 24, 6905-6916. [CrossRef]

14. Li, R.; Wu, H.; Ding, J.; Fu, W.; Gan, L.; Li, Y. Mercury pollution in vegetables, grains and soils from areas surrounding coal-fired power plants. Sci. Rep. 2017, 7, 46545. [CrossRef]

15. Inoue, S.; Yorifuji, T.; Tsuda, T.; Doi, H. Short-term effect of severe exposure to methylmercury on atherosclerotic heart disease and hypertension mortality in Minamata. Sci. Total Environ. 2012, 417-418, 291-293. [CrossRef]

16. Guallar, E.; Sanz-Gallardo, M.I.; van't Veer, P.; Bode, P.; Aro, A.; Gómez-Aracena, J.; Kark, J.D.; Riemersma, R.A.; Martín-Moreno, J.M.; Kok, F.J. Mercury, Fish Oils, and the Risk of Myocardial Infarction. N. Engl. J. Med. 2002, 347, 1747-1754. [CrossRef]

17. Choi, B.; Yeum, K.-J.; Park, S.-J.; Kim, K.-N.; Joo, N.-S. Elevated serum ferritin and mercury concentrations are associated with hypertension; analysis of the fourth and fifth Korea national health and nutrition examination survey (KNHANES IV-2, 3, 2008-2009 and V-1, 2010). Environ. Toxicol. 2015, 30, 101-108. [CrossRef]

18. Tinkov, A.A.; Ajsuvakova, O.P.; Skalnaya, M.G.; Popova, E.V.; Sinitskii, A.I.; Nemereshina, O.N.; Gatiatulina, E.R.; Nikonorov, A.A.; Skalny, A.V. Mercury and metabolic syndrome: A review of experimental and clinical observations. Biomet. Int. J. Role Met. Ions Biol. Biochem. Med. 2015, 28, 231-254. [CrossRef]

19. Rajaee, M.; Sánchez, B.N.; Renne, E.P.; Basu, N. An Investigation of Organic and Inorganic Mercury Exposure and Blood Pressure in a Small-Scale Gold Mining Community in Ghana. Int. J. Environ. Res. Public. Health 2015, 12, 10020-10038. [CrossRef]

20. Haybar, H.; Shahrabi, S.; Rezaeeyan, H.; Shirzad, R.; Saki, N. Endothelial Cells: From Dysfunction Mechanism to Pharmacological Effect in Cardiovascular Disease. Cardiovasc. Toxicol. 2019, 19, 13-22. [CrossRef]

21. Small, H.Y.; Migliarino, S.; Czesnikiewicz-Guzik, M.; Guzik, T.J. Hypertension: Focus on autoimmunity and oxidative stress. Free Radic. Biol. Med. 2018, 125, 104-115. [CrossRef]

22. Pierozan, P.; Biasibetti, H.; Schmitz, F.; Ávila, H.; Fernandes, C.G.; Pessoa-Pureur, R.; Wyse, A.T.S. Neurotoxicity of Methylmercury in Isolated Astrocytes and Neurons: The Cytoskeleton as a Main Target. Mol. Neurobiol. 2017, 54, 5752-5767. [CrossRef]

23. Robitaille, S.; Mailloux, R.J.; Chan, H.M. Methylmercury alters glutathione homeostasis by inhibiting glutaredoxin 1 and enhancing glutathione biosynthesis in cultured human astrocytoma cells. Toxicol. Lett. 2016, 256, 1-10. [CrossRef] [PubMed]

24. Meinerz, D.F.; Branco, V.; Aschner, M.; Carvalho, C.; Rocha, J.B.T. Diphenyl diselenide protects against methylmercury-induced inhibition of thioredoxin reductase and glutathione peroxidase in human neuroblastoma cells: A comparison with ebselen. J. Appl. Toxicol. JAT 2017, 37, 1073-1081. [CrossRef] [PubMed] 
25. Usuki, F.; Fujimura, M. Decreased plasma thiol antioxidant barrier and selenoproteins as potential biomarkers for ongoing methylmercury intoxication and an individual protective capacity. Arch. Toxicol. 2016, 90, 917-926. [CrossRef]

26. Kirkpatrick, M.; Benoit, J.; Everett, W.; Gibson, J.; Rist, M.; Fredette, N. The effects of methylmercury exposure on behavior and biomarkers of oxidative stress in adult mice. Neurotoxicology 2015, 50, 170-178. [CrossRef]

27. Al Bakheet, S.A.; Attafi, I.M.; Maayah, Z.H.; Abd-Allah, A.R.; Asiri, Y.A.; Korashy, H.M. Effect of long-term human exposure to environmental heavy metals on the expression of detoxification and DNA repair genes. Environ. Pollut. 2013, 181, 226-232. [CrossRef]

28. Karimi, R.; Vacchi-Suzzi, C.; Meliker, J.R. Mercury exposure and a shift toward oxidative stress in avid seafood consumers. Environ. Res. 2016, 146, 100-107. [CrossRef] [PubMed]

29. Al-Zubaidi, E.S.; Rabee, A.M. The risk of occupational exposure to mercury vapor in some public dental clinics of Baghdad city, Iraq. Inhal. Toxicol. 2017, 29, 397-403. [CrossRef]

30. Magos, L.; Clarkson, T.W. Overview of the clinical toxicity of mercury. Ann. Clin. Biochem. 2006, 43, 257-268. [CrossRef]

31. Clarkson, T.W. The Toxicology of Mercury. Crit. Rev. Clin. Lab. Sci. 1997, 34, 369-403. [CrossRef] [PubMed]

32. Schläwicke Engström, K.; Strömberg, U.; Lundh, T.; Johansson, I.; Vessby, B.; Hallmans, G.; Skerfving, S.; Broberg, K. Genetic variation in glutathione-related genes and body burden of methylmercury. Environ. Health Perspect. 2008, 116, 734-739. [CrossRef] [PubMed]

33. Barcelos, G.R.M.; De Marco, K.C.; de Rezende, V.B.; Braga, G.Ú.L.; Antunes, L.M.G.; Tanus-Santos, J.E.; Barbosa, F. Genetic Effects of eNOS Polymorphisms on Biomarkers Related to Cardiovascular Status in a Population Coexposed to Methylmercury and Lead. Arch. Environ. Contam. Toxicol. 2015, 69, $173-180$. [CrossRef] [PubMed]

34. de Oliveira, A.Á.S.; de Souza, M.F.; van Lengert, A.H.; de Oliveira, M.T.; de Camargo, R.B.O.G.; Braga, G.Ú.L.; de Cólus, I.M.S.; Barbosa, F.; Barcelos, G.R.M. Genetic polymorphisms in glutathione (GSH-) related genes affect the plasmatic $\mathrm{Hg} /$ whole blood $\mathrm{Hg}$ partitioning and the distribution between inorganic and methylmercury levels in plasma collected from a fish-eating population. BioMed Res. Int. 2014, $2014,940952$. [CrossRef] [PubMed]

35. Mori, N.; Yasutake, A.; Hirayama, K. Comparative study of activities in reactive oxygen species production/defense system in mitochondria of rat brain and liver, and their susceptibility to methylmercury toxicity. Arch. Toxicol. 2007, 81, 769-776. [CrossRef]

36. Lockman, P.R.; Roder, K.E.; Allen, D.D. Inhibition of the rat blood-brain barrier choline transporter by manganese chloride. J. Neurochem. 2001, 79, 588-594. [CrossRef] [PubMed]

37. Omanwar, S.; Fahim, M. Mercury Exposure and Endothelial Dysfunction: An Interplay Between Nitric Oxide and Oxidative Stress. Int. J. Toxicol. 2015, 34, 300-307. [CrossRef] [PubMed]

38. Wiggers, G.A.; Furieri, L.B.; Briones, A.M.; Avendaño, M.S.; Peçanha, F.M.; Vassallo, D.V.; Salaices, M.; Alonso, M.J. Cerebrovascular endothelial dysfunction induced by mercury exposure at low concentrations. NeuroToxicology 2016, 53, 282-289. [CrossRef] [PubMed]

39. Boffetta, P.; Sällsten, G.; Garcia-Gómez, M.; Pompe-Kirn, V.; Zaridze, D.; Bulbulyan, M.; Caballero, J.D.; Ceccarelli, F.; Kobal, A.B.; Merler, E. Mortality from cardiovascular diseases and exposure to inorganic mercury. Occup. Environ. Med. 2001, 58, 461-466. [CrossRef]

40. Torres, A.D.; Rai, A.N.; Hardiek, M.L. Mercury intoxication and arterial hypertension: report of two patients and review of the literature. Pediatrics 2000, 105, E34. [CrossRef]

41. Salonen, J.T.; Seppänen, K.; Lakka, T.A.; Salonen, R.; Kaplan, G.A. Mercury accumulation and accelerated progression of carotid atherosclerosis: a population-based prospective 4-year follow-up study in men in eastern Finland. Atherosclerosis 2000, 148, 265-273. [CrossRef]

42. Houston, M.C. Role of Mercury Toxicity in Hypertension, Cardiovascular Disease, and Stroke: Role of Mercury Toxicity in Hypertension. J. Clin. Hypertens. 2011, 13, 621-627. [CrossRef] [PubMed]

43. Magos, L.; Webb, M.; Clarkson, T.W. The interactions of selenium with cadmium and mercury. CRC Crit. Rev. Toxicol. 1980, 8, 1-42. [CrossRef] [PubMed]

44. Kishimoto, T.; Oguri, T.; Abe, M.; Kajitani, H.; Tada, M. Inhibitory effect of methylmercury on migration and tube formation by cultured human vascular endothelial cells. Arch. Toxicol. 1995, 69, 357-361. [CrossRef] [PubMed] 
45. VAN Dao, C.; Islam, M.Z.; Sudo, K.; Shiraishi, M.; Miyamoto, A. MARCKS is involved in methylmercuryinduced decrease in cell viability and nitric oxide production in EA.hy926 cells. J. Vet. Med. Sci. 2016, 78, 1569-1576. [CrossRef] [PubMed]

46. Lu, K.P.; Zhao, S.H.; Wang, D.S. The stimulatory effect of heavy metal cations on proliferation of aortic smooth muscle cells. Sci. China B 1990, 33, 303-310. [PubMed]

47. Kostka, B.; Michalska, M.; Krajewska, U.; Wierzbicki, R. Blood coagulation changes in rats poisoned with methylmercuric chloride (MeHg). Pol. J. Pharmacol. Pharm. 1989, 41, 183-189. [PubMed]

48. Ally, A.; Buist, R.; Mills, P.; Reuhl, K. Effects of methylmercury and trimethyltin on cardiac, platelet, and aorta eicosanoid biosynthesis and platelet serotonin release. Pharmacol. Biochem. Behav. 1993, 44, 555-563. [CrossRef]

49. Wierzbicki, R.; Pra?anowski, M.; Michalska, M.; Krajewska, U.; Mielicki, W.P. Disorders in blood coagulation in humans occupationally exposed to mercuric vapors. J. Trace Elem. Exp. Med. 2002, 15, 21-29. [CrossRef]

50. Kerper, L.E.; Ballatori, N.; Clarkson, T.W. Methylmercury transport across the blood-brain barrier by an amino acid carrier. Am. J. Physiol.-Regul. Integr. Comp. Physiol. 1992, 262, R761-R765. [CrossRef]

51. Yanagida, O.; Kanai, Y.; Chairoungdua, A.; Kim, D.K.; Segawa, H.; Nii, T.; Cha, S.H.; Matsuo, H.; Fukushima, J.; Fukasawa, Y.; et al. Human L-type amino acid transporter 1 (LAT1): characterization of function and expression in tumor cell lines. Biochim. Biophys. Acta 2001, 1514, 291-302. [CrossRef]

52. Yin, Z.; Jiang, H.; Syversen, T.; Rocha, J.B.T.; Farina, M.; Aschner, M. The methylmercury-l-cysteine conjugate is a substrate for the L-type large neutral amino acid transporter. J. Neurochem. 2008, 107, 1083-1090. [CrossRef] [PubMed]

53. Miura, K.; Koide, N.; Himeno, S.; Nakagawa, I.; Imura, N. The Involvement of Microtubular Disruption in Methylmercury-Induced Apoptosis in Neuronal and Nonneuronal Cell Lines. Toxicol. Appl. Pharmacol. 1999, 160, 279-288. [CrossRef] [PubMed]

54. Vogel, D.G.; Margolis, R.L.; Mottet, N.K. The effects of methyl mercury binding to microtubules. Toxicol. Appl. Pharmacol. 1985, 80, 473-486. [CrossRef]

55. Fonfría, E.; Rodríguez-Farré, E.; Suñol, C. Mercury interaction with the GABA(A) receptor modulates the benzodiazepine binding site in primary cultures of mouse cerebellar granule cells. Neuropharmacology 2001, 41, 819-833. [CrossRef]

56. Juárez, B.I.; Portillo-Salazar, H.; González-Amaro, R.; Mandeville, P.; Aguirre, J.R.; Jiménez, M.E. Participation of N-methyl-d-aspartate receptors on methylmercury-induced DNA damage in rat frontal cortex. Toxicology 2005, 207, 223-229. [CrossRef] [PubMed]

57. Miyamoto, K.; Nakanishi, H.; Moriguchi, S.; Fukuyama, N.; Eto, K.; Wakamiya, J.; Murao, K.; Arimura, K.; Osame, M. Involvement of enhanced sensitivity of $\mathrm{N}$-methyl- $\mathrm{d}$-aspartate receptors in vulnerability of developing cortical neurons to methylmercury neurotoxicity. Brain Res. 2001, 901, 252-258. [CrossRef]

58. Antunes dos Santos, A.; Ferrer, B.; Marques Gonçalves, F.; Tsatsakis, A.; Renieri, E.; Skalny, A.; Farina, M.; Rocha, J.; Aschner, M. Oxidative Stress in Methylmercury-Induced Cell Toxicity. Toxics 2018, 6, 47. [CrossRef]

59. Ceccatelli, S.; Daré, E.; Moors, M. Methylmercury-induced neurotoxicity and apoptosis. Chem. Biol. Interact. 2010, 188, 301-308. [CrossRef]

60. do Nascimento, J.L.M.; Oliveira, K.R.M.; Crespo-Lopez, M.E.; Macchi, B.M.; Maués, L.A.L.; da Pinheiro, M.C.N.; Silveira, L.C.L.; Herculano, A.M. Methylmercury neurotoxicity \& antioxidant defenses. Indian J. Med. Res. 2008, 128, 373-382.

61. Niizuma, K.; Endo, H.; Chan, P.H. Oxidative stress and mitochondrial dysfunction as determinants of ischemic neuronal death and survival. J. Neurochem. 2009, 109 (Suppl. 1), 133-138. [CrossRef]

62. Chamorro, Á.; Dirnagl, U.; Urra, X.; Planas, A.M. Neuroprotection in acute stroke: targeting excitotoxicity, oxidative and nitrosative stress, and inflammation. Lancet Neurol. 2016, 15, 869-881. [CrossRef]

63. Burbulla, L.F.; Song, P.; Mazzulli, J.R.; Zampese, E.; Wong, Y.C.; Jeon, S.; Santos, D.P.; Blanz, J.; Obermaier, C.D.; Strojny, C.; et al. Dopamine oxidation mediates mitochondrial and lysosomal dysfunction in Parkinson's disease. Science 2017, 357, 1255-1261. [CrossRef] 
64. Grassi, D.; Howard, S.; Zhou, M.; Diaz-Perez, N.; Urban, N.T.; Guerrero-Given, D.; Kamasawa, N.; Volpicelli-Daley, L.A.; LoGrasso, P.; Lasmézas, C.I. Identification of a highly neurotoxic $\alpha$-synuclein species inducing mitochondrial damage and mitophagy in Parkinson's disease. Proc. Natl. Acad. Sci. USA 2018, 115, E2634-E2643. [CrossRef]

65. Guo, J.-D.; Zhao, X.; Li, Y.; Li, G.-R.; Liu, X.-L. Damage to dopaminergic neurons by oxidative stress in Parkinson's disease (Review). Int. J. Mol. Med. 2018, 41, 1817-1825. [CrossRef]

66. Hoekstra, J.G.; Hipp, M.J.; Montine, T.J.; Kennedy, S.R. Mitochondrial DNA mutations increase in early stage Alzheimer disease and are inconsistent with oxidative damage. Ann. Neurol. 2016, 80, 301-306. [CrossRef]

67. Swomley, A.M.; Butterfield, D.A. Oxidative stress in Alzheimer disease and mild cognitive impairment: evidence from human data provided by redox proteomics. Arch. Toxicol. 2015, 89, 1669-1680. [CrossRef]

68. García-Blanco, A.; Baquero, M.; Vento, M.; Gil, E.; Bataller, L.; Cháfer-Pericás, C. Potential oxidative stress biomarkers of mild cognitive impairment due to Alzheimer disease. J. Neurol. Sci. 2017, 373, $295-302$. [CrossRef]

69. Álvarez-Zaldiernas, C.; Lu, J.; Zheng, Y.; Yang, H.; Blasi, J.; Solsona, C.; Holmgren, A. Cellular Redox Systems Impact the Aggregation of $\mathrm{Cu}, \mathrm{Zn}$ Superoxide Dismutase Linked to Familial Amyotrophic Lateral Sclerosis. J. Biol. Chem. 2016, 291, 17197-17208. [CrossRef]

70. Peters, O.M.; Ghasemi, M.; Brown, R.H. Emerging mechanisms of molecular pathology in ALS. J. Clin. Investig. 2015, 125, 1767-1779. [CrossRef]

71. Wang, H.; Guo, W.; Mitra, J.; Hegde, P.M.; Vandoorne, T.; Eckelmann, B.J.; Mitra, S.; Tomkinson, A.E.; Van Den Bosch, L.; Hegde, M.L. Mutant FUS causes DNA ligation defects to inhibit oxidative damage repair in Amyotrophic Lateral Sclerosis. Nat. Commun. 2018, 9, 3683. [CrossRef]

72. Yin, Z.; Lee, E.; Ni, M.; Jiang, H.; Milatovic, D.; Rongzhu, L.; Farina, M.; Rocha, J.B.T.; Aschner, M. Methylmercury-induced alterations in astrocyte functions are attenuated by ebselen. Neurotoxicology 2011, 32, 291-299. [CrossRef]

73. Zhang, P.; Xu, Y.; Sun, J.; Li, X.; Wang, L.; Jin, L. Protection of pyrroloquinoline quinone against methylmercury-induced neurotoxicity via reducing oxidative stress. Free Radic. Res. 2009, 43, $224-233$. [CrossRef]

74. Ganther, H.E. Modification of methylmercury toxicity and metabolism by selenium and vitamin E: possible mechanisms. Environ. Health Perspect. 1978, 25, 71-76. [CrossRef]

75. Farina, M.; Campos, F.; Vendrell, I.; Berenguer, J.; Barzi, M.; Pons, S.; Suñol, C. Probucol Increases Glutathione Peroxidase-1 Activity and Displays Long-Lasting Protection against Methylmercury Toxicity in Cerebellar Granule Cells. Toxicol. Sci. 2009, 112, 416-426. [CrossRef]

76. Chang, J.Y. Methylmercury-induced IL-6 release requires phospholipase C activities. Neurosci. Lett. 2011, 496, 152-156. [CrossRef]

77. InSug, O.; Datar, S.; Koch, C.J.; Shapiro, I.M.; Shenker, B.J. Mercuric compounds inhibit human monocyte function by inducing apoptosis: evidence for formation of reactive oxygen species, development of mitochondrial membrane permeability transition and loss of reductive reserve. Toxicology 1997, 124, 211-224. [CrossRef]

78. Kim, S.H.; Johnson, V.J.; Sharma, R.P. Oral exposure to inorganic mercury alters T lymphocyte phenotypes and cytokine expression in BALB/c mice. Arch. Toxicol. 2003, 77, 613-620. [CrossRef]

79. Kanazawa, M.; Ninomiya, I.; Hatakeyama, M.; Takahashi, T.; Shimohata, T. Microglia and Monocytes/ Macrophages Polarization Reveal Novel Therapeutic Mechanism against Stroke. Int. J. Mol. Sci. 2017, 18, 2135. [CrossRef]

80. Winkler, E.A.; Bell, R.D.; Zlokovic, B.V. Central nervous system pericytes in health and disease. Nat. Neurosci. 2011, 14, 1398-1405. [CrossRef]

81. Lin, S.-L.; Kisseleva, T.; Brenner, D.A.; Duffield, J.S. Pericytes and perivascular fibroblasts are the primary source of collagen-producing cells in obstructive fibrosis of the kidney. Am. J. Pathol. 2008, 173, 1617-1627. [CrossRef]

82. Park, T.I.-H.; Feisst, V.; Brooks, A.E.S.; Rustenhoven, J.; Monzo, H.J.; Feng, S.X.; Mee, E.W.; Bergin, P.S.; Oldfield, R.; Graham, E.S.; et al. Cultured pericytes from human brain show phenotypic and functional differences associated with differential CD90 expression. Sci. Rep. 2016, 6, 26587. [CrossRef] [PubMed]

83. ElAli, A.; Thériault, P.; Rivest, S. The Role of Pericytes in Neurovascular Unit Remodeling in Brain Disorders. Int. J. Mol. Sci. 2014, 15, 6453-6474. [CrossRef] 
84. Shanker, G.; Syversen, T.; Aschner, M. Astrocyte-mediated methylmercury neurotoxicity. Biol. Trace Elem. Res. 2003, 95, 1-10. [CrossRef]

85. Berezowski, V.; Fukuda, A.M.; Cecchelli, R.; Badaut, J. Endothelial cells and astrocytes: a concerto en duo in ischemic pathophysiology. Int. J. Cell Biol. 2012, 2012, 176287. [CrossRef]

86. Potokar, M.; Jorgačevski, J.; Zorec, R. Astrocyte Aquaporin Dynamics in Health and Disease. Int. J. Mol. Sci. 2016, 17, 1121. [CrossRef]

87. McBean, G.J. Astrocyte Antioxidant Systems. Antioxid. Basel Switz. 2018, 7, 112. [CrossRef]

88. Kimelberg, H.K.; Nedergaard, M. Functions of astrocytes and their potential as therapeutic targets. Neurother. J. Am. Soc. Exp. Neurother. 2010, 7, 338-353. [CrossRef]

89. Sandoval, K.E.; Witt, K.A. Blood-brain barrier tight junction permeability and ischemic stroke. Neurobiol. Dis. 2008, 32, 200-219. [CrossRef]

90. Zhou, J.; Stohlman, S.A.; Hinton, D.R.; Marten, N.W. Neutrophils promote mononuclear cell infiltration during viral-induced encephalitis. J. Immunol. Baltim. Md 1950 2003, 170, 3331-3336. [CrossRef]

91. Shlosberg, D.; Benifla, M.; Kaufer, D.; Friedman, A. Blood-brain barrier breakdown as a therapeutic target in traumatic brain injury. Nat. Rev. Neurol. 2010, 6, 393-403. [CrossRef] [PubMed]

92. Hirooka, T.; Fujiwara, Y.; Yamamoto, C.; Yasutake, A.; Kaji, T. Methylmercury Retards the Repair of Wounded Monolayer of Human Brain Microvascular Endothelial Cells by Inhibiting Their Proliferation without Nonspecific Cell Damage. J. Health Sci. 2007, 53, 450-456. [CrossRef]

93. Hirooka, T.; Fujiwara, Y.; Inoue, S.; Shinkai, Y.; Yamamoto, C.; Satoh, M.; Yasutake, A.; Eto, K.; Kaji, T. Suppression of fibroblast growth factor-2 expression: Possible mechanism underlying methylmercury-induced inhibition of the repair of wounded monolayers of cultured human brain microvascular endothelial cells. J. Toxicol. Sci. 2009, 34, 433-439. [CrossRef] [PubMed]

94. Hirooka, T.; Yamamoto, C.; Yasutake, A.; Eto, K.; Kaji, T. Expression of VEGF-related proteins in cultured human brain microvascular endothelial cells and pericytes after exposure to methylmercury. J. Toxicol. Sci. 2013, 38, 837-845. [CrossRef] [PubMed]

95. Ferrara, N.; Gerber, H.-P.; LeCouter, J. The biology of VEGF and its receptors. Nat. Med. 2003, 9, 669-676. [CrossRef] [PubMed]

96. Hirooka, T.; Fujiwara, Y.; Minami, Y.; Ishii, A.; Ishigooka, M.; Shinkai, Y.; Yamamoto, C.; Satoh, M.; Yasutake, A.; Eto, K.; et al. Cell-density-dependent methylmercury susceptibility of cultured human brain microvascular pericytes. Toxicol. In Vitro 2010, 24, 835-841. [CrossRef] [PubMed]

97. Yemisci, M.; Gursoy-Ozdemir, Y.; Vural, A.; Can, A.; Topalkara, K.; Dalkara, T. Pericyte contraction induced by oxidative-nitrative stress impairs capillary reflow despite successful opening of an occluded cerebral artery. Nat. Med. 2009, 15, 1031-1037. [CrossRef]

98. Hirooka, T.; Yoshida, E.; Eto, K.; Kaji, T. Methylmercury induces hyaluronan synthesis in cultured human brain microvascular endothelial cells and pericytes via different mechanisms. J. Toxicol. Sci. 2017, 42, 329-333. [CrossRef]

99. Noguchi, Y.; Shinozaki, Y.; Fujishita, K.; Shibata, K.; Imura, Y.; Morizawa, Y.; Gachet, C.; Koizumi, S. Astrocytes Protect Neurons against Methylmercury via ATP/P2Y1 Receptor-Mediated Pathways in Astrocytes. PLoS ONE 2013, 8, e57898. [CrossRef]

100. Badaut, J.; Lasbennes, F.; Magistretti, P.J.; Regli, L. Aquaporins in brain: distribution, physiology, and pathophysiology. J. Cereb. Blood Flow Metab. Off. J. Int. Soc. Cereb. Blood Flow Metab. 2002, 22, 367-378. [CrossRef]

101. Yukutake, Y.; Tsuji, S.; Hirano, Y.; Adachi, T.; Takahashi, T.; Fujihara, K.; Agre, P.; Yasui, M.; Suematsu, M. Mercury chloride decreases the water permeability of aquaporin-4-reconstituted proteoliposomes. Biol. Cell 2008, 100, 355-363. [CrossRef]

102. Cao, S.; Zhu, P.; Yu, X.; Chen, J.; Li, J.; Yan, F.; Wang, L.; Yu, J.; Chen, G. Hydrogen sulfide attenuates brain edema in early brain injury after subarachnoid hemorrhage in rats: Possible involvement of MMP-9 induced blood-brain barrier disruption and AQP4 expression. Neurosci. Lett. 2016, 621, 88-97. [CrossRef]

103. Tait, M.J.; Saadoun, S.; Bell, B.A.; Verkman, A.S.; Papadopoulos, M.C. Increased brain edema in aqp4-null mice in an experimental model of subarachnoid hemorrhage. Neuroscience 2010, 167, 60-67. [CrossRef] [PubMed] 
104. Manley, G.T.; Fujimura, M.; Ma, T.; Noshita, N.; Filiz, F.; Bollen, A.W.; Chan, P.; Verkman, A.S. Aquaporin-4 deletion in mice reduces brain edema after acute water intoxication and ischemic stroke. Nat. Med. 2000, 6, 159-163. [CrossRef] [PubMed]

105. Kitchen, P.; Day, R.E.; Taylor, L.H.J.; Salman, M.M.; Bill, R.M.; Conner, M.T.; Conner, A.C. Identification and Molecular Mechanisms of the Rapid Tonicity-induced Relocalization of the Aquaporin 4 Channel. J. Biol. Chem. 2015, 290, 16873-16881. [CrossRef] [PubMed]

106. Sturdivant, N.M.; Smith, S.G.; Ali, S.F.; Wolchok, J.C.; Balachandran, K. Acetazolamide Mitigates Astrocyte Cellular Edema Following Mild Traumatic Brain Injury. Sci. Rep. 2016, 6, 33330. [CrossRef]

107. Lohren, H.; Bornhorst, J.; Fitkau, R.; Pohl, G.; Galla, H.-J.; Schwerdtle, T. Effects on and transfer across the blood-brain barrier in vitro-Comparison of organic and inorganic mercury species. BMC Pharmacol. Toxicol. 2016, 17, 63. [CrossRef] [PubMed]

108. Takahashi, T.; Fujimura, M.; Koyama, M.; Kanazawa, M.; Usuki, F.; Nishizawa, M.; Shimohata, T. Methylmercury Causes Blood-Brain Barrier Damage in Rats via Upregulation of Vascular Endothelial Growth Factor Expression. PLOS ONE 2017, 12, e0170623. [CrossRef]

109. Silwedel, C.; Förster, C. Differential susceptibility of cerebral and cerebellar murine brain microvascular endothelial cells to loss of barrier properties in response to inflammatory stimuli. J. Neuroimmunol. 2006, 179, 37-45. [CrossRef]

110. Wilhelm, I.; Nyúl-Tóth, Á.; Suciu, M.; Hermenean, A.; Krizbai, I.A. Heterogeneity of the blood-brain barrier. Tissue Barriers 2016, 4, e1143544. [CrossRef]

111. Phares, T.W.; Kean, R.B.; Mikheeva, T.; Hooper, D.C. Regional Differences in Blood-Brain Barrier Permeability Changes and Inflammation in the Apathogenic Clearance of Virus from the Central Nervous System. J. Immunol. 2006, 176, 7666-7675. [CrossRef]

112. Fabis, M.J.; Phares, T.W.; Kean, R.B.; Koprowski, H.; Hooper, D.C. Blood-brain barrier changes and cell invasion differ between therapeutic immune clearance of neurotrophic virus and CNS autoimmunity. Proc. Natl. Acad. Sci. USA 2008, 105, 15511-15516. [CrossRef] [PubMed]

113. Kuwabara, S.; Dispenzieri, A.; Arimura, K.; Misawa, S.; Nakaseko, C. Treatment for POEMS (polyneuropathy, organomegaly, endocrinopathy, M-protein, and skin changes) syndrome. Cochrane Database Syst. Rev. 2012. [CrossRef]

114. Kanazawa, M.; Igarashi, H.; Kawamura, K.; Takahashi, T.; Kakita, A.; Takahashi, H.; Nakada, T.; Nishizawa, M.; Shimohata, T. Inhibition of VEGF signaling pathway attenuates hemorrhage after tPA treatment. J. Cereb. Blood Flow Metab. 2011, 31, 1461-1474. [CrossRef] [PubMed]

115. Coultas, L.; Chawengsaksophak, K.; Rossant, J. Endothelial cells and VEGF in vascular development. Nature 2005, 438, 937-945. [CrossRef]

116. Wax, P.M. Current use of chelation in American health care. J. Med. Toxicol. Off. J. Am. Coll. Med. Toxicol. 2013, 9, 303-307. [CrossRef] [PubMed]

117. Böse-O'Reilly, S.; Drasch, G.; Beinhoff, C.; Maydl, S.; Vosko, M.R.; Roider, G.; Dzaja, D. The Mt. Diwata study on the Philippines 2000-treatment of mercury intoxicated inhabitants of a gold mining area with DMPS (2,3-dimercapto-1-propane-sulfonic acid, Dimaval). Sci. Total Environ. 2003, 307, 71-82. [CrossRef]

(C) 2019 by the authors. Licensee MDPI, Basel, Switzerland. This article is an open access article distributed under the terms and conditions of the Creative Commons Attribution (CC BY) license (http://creativecommons.org/licenses/by/4.0/). 